\title{
Art Competitions at the Olympic Games 1912-1948 and the Czechoslovak participation
}

\author{
Zdeněk Škoda
}

Czech Olympic Academy

\section{Methodology}

This article is a historical contribution. The historical data was gained mainly from primary sources and relevant literature. I have worked mainly with official reports from the Olympic Games, the estate of the Secretary-General of the Czechoslovak Olympic Committee František Widimský, documents from the archive of the Czech Olympic Committee and published articles by members of International Society of Olympic Historians. The methods that were used were direct and indirect historical approach, biography method and progressive method.

\section{INTRODUCTION}

Ten years after Pierre de Coubertin's dream came true and the International Olympic Committee (IOC) was set up, and with it later re-established the Olympic Games, he came up with the bold idea of including sports competitions and art competitions in the Olympic program. The ideal of modern Olympism refers to the ancient Greek idea of kalokagathia, the union of soul and body into one harmonious whole. According to Coubertin, the Olympic Games should be a fusion of sport and art.

In August 1904, the words of Coubertin were published in the Italian newspaper Figaro: "Time to come to the next step, and to restore the Olympiad to its primal beauty. At the time of Olympia's splendour... the arts and literature in a harmonious combination with sports made the Olympic Games great. The same must hold for the future." (Coubertin, Müller, 2000, p. 605).

In a circular dated April 4, 1906, Coubertin invited the members of the IOC and asked them to nominate artists from their countries to be invited to the Advisory Conference in Paris: "...art and literature can participate in the celebration of modern Olympiads..." was said in the letter (Müller, 1994, p. 70).

At this conference, Coubertin officially proposed that the IOC should organize a competition of artists and works of art in five different disciplines: architecture, music, sculpture, literature and fine arts. A kind of pentathlon muse. All works of art, without exception, are to be inspired by sport and to be original, meaning that it should not have been published on another occasion, and not before the Olympic Games. It was planned that the forthcoming Olympic Games in 1908, which were originally scheduled to take place in Rome, would organize art competitions. However, the Italians had unexpected financial problems in preparing the games (Müller, 2000, p. 623-624). By the way, they were caused, besides other things, by the eruption of Mount Vesuvius in $1906^{1}$. As a result, preparations for the Games had to stop. London was chosen hastily, and although the British wished for the art competitions to take place in the English capital, due to lack of time of organizing them, the art competitions were eventually withdrawn as part of the Olympic Games.

\footnotetext{
1 Vesuvius Threatens Destructions of Towns. (1906, April 6). New York Times. Retrieved in December 14, 2019, from https://timesmachine.nytimes.com/timesmachine/1906/04/07/101838227.pdf
} 


\section{Art competitions at the Olympic Games - from Stockholm 1912 to London 1948}

This initial failure did not discourage Coubertin and he strained all his will to Stockholm 1912. But the Organizing Committee for the Games in Stockholm did not receive support from various Swedish art associations and other institutions, including the Royal Swedish Academy, and all ended with the decision that the IOC had to be involved. Coubertin took the matter under his responsibility. And it ended in a fiasco. Only 35 artists entered the competitions. Disappointment. One work, however, impressed the jury. A poem in prose called Ode to Sport. It won the first place for literature. The authors of the work were two unknown writers Georges Hohrod and Martin Eschbach. As it turned out later, it was Coubertin's pseudonyms... (Lennartz, 2006).

It wasn't known until the 1990s when Jean Durry, a historian and an Olympic official, discovered that these two names were in fact the names of two villages near Luttenbach near Colmar, where Coubertin's wife was born. (Durry, 2000)

The Games of the VI Olympiad took place in Antwerp. Belgium (the country of fine arts) took the honour of organizing art competitions and took them very prestigiously. The works were of much higher quality than at the Stockholm Games. For the first time, all three medals were awarded, following the example of the awarding of athletes. Still, the competition of artists was only a marginal matter and without much interest.

It finally changed at The Games of the VIII Olympiad in Paris. In Coubertin's homeland, the artistic competitions were equal in importance to sports competitions. Almost $200 \mathrm{artists}^{2}$ from 24 countries applied to Paris. The interest in participating in the competitions in any ways was so great that the judges were often more famous than the competitors themselves. Judge for yourself: Paul Valéry ${ }^{3}$, Selma Lagerlöf $f^{4}$, Maurice Ravel ${ }^{5}$ or even Igor Stravinsky ${ }^{6}$ appeared among the judges. The music jury, by the way, did not give a medal to any musical work or composer and gave only diplomas for an "effort"? Apparently, they were not amazed about the quality of the songs. It is also interesting that three artists from the Soviet Union took part in the competition. Because for the first time the Soviets officially started in Helsinki in 1952.

In 1925, at the IOC meeting in Prague, Pierre de Coubertin resigned from the IOC leadership on his own initiative and was elected a lifelong honorary member. ${ }^{8}$

A year later, the International Olympic Committee decided to set up an International Jury for the art competitions. Artistic quality was no longer decided by art professionals but by functionaries of IOC (Bijkerk, 2006, p. 29).

In Amsterdam 1928 the increase in popularity continued. More than 1,100 works have been exhibited at the City Museum. Architectural works were allowed to be published before the

2 Here we should mention Hungarian Alfréd Hajós (1878-1955), the first Olympic Champion swimmer, winner of Hungary's first Olympic gold medal in Athens 1896, who also won the Art Competition of the Paris 1924 Olympic Games, in the category of Architecture. In the whole long history of modern Olympism, Alfréd Hajós remains to be the only athlete to win an Olympic competition in both sports and art.

3 Paul Valéry (1871-1945) was a French poet, essayist and philosopher. In addition to his poetry and fiction (drama and dialogues), his interests included aphorism on art, history, letters, music, and current events.

4 Selma Lagerlöw (1858-1940) was a Swedish author and teacher, she was the first female writer to win the Nobel Prize in Literature, which she was awarded in 1909.

5 Maurice Ravel (1875-1937) was a French composer, pianist and conductor. His best-known work is Bolero (1928).

6 Igor Stravinsky (1882-1971) was a Russian composer, pianist, and conductor. He is widely considered one of the most important and influential in the 20th century.

7 Art Competitions at the 1924 Paris Summer Games: Mixed Music. Retrieved in November 20, 2019, from https://www.sports-reference.com/olympics/summer/1924/ART/mixed-music.html.

8 More information in Kolář, F. (1999). Jiří Stanislav Guth Jarkovský (pp. 73-74). Praha: Olympia. The text is concurrent in English. 
Olympic Games. So, for example Jan Wils ${ }^{9}$ was able to win a gold medal for the project of the local Olympic Stadium, where the Amsterdam games took place.

Because of the economic crisis and the expensive and long journey to Los Angeles, the 1932 Olympic Games were attended by far fewer athletes than in previous games. Paradoxically, this did not concern works of art. They were mostly sent by the ocean alone without the authors, and the Americans went to help ensure their transportation and insurance. An incredible 384,000 visitors came to the Los Angeles Museum of History, Science and Art in the story of the Games, which was historically the highest attendance ever.

Then came Berlin 1936. The German Art Committee, headed by Joseph Göbless, the German Minister for Folk Education and Propaganda, wanted the competitions in Berlin to be expanded so that the Germans had far more opportunities to show up themselves and succeed in an international competition. They tried to promote the film as another discipline, then they tried it with dance. Coubertin, however, strictly wished to maintain five disciplines. He considered the number 5 as an Olympic symbol (five circles, modern pentathlon...); and the IOC was also behind this. However, the Germans managed to expand the individual categories. So, for example, the music competition had three subcategories: orchestral composition, instrumental music, solo and choral singing. Or sculpture was divided into statues, reliefs, medallions. (Zawadski, 2006, p. 51-54). However, this was not a novelty: already in Amsterdam 1928 in literature the writers competed separately in drama, epic and lyric and also music was split up in three categories (Bijkerk, 2006, p. 30).

After World War II, the Olympic Games returned to London after 40 years. And there were two major changes in the rules: 1) only living artists were allowed to participate and 2) the works had to be first approved by the individual National Olympic Committees of the country from which the artist came from, so that it could no longer appear the work of someone whose country officially did not start at the Olympics, as was the case with the Soviets in Paris in 1924. The art competitions in London 1948 included multiple subcategories for each of the five artistic categories. The complexity of the competition with so many categories lading to devaluation of the Olympic medal (Guillain, 2005). "There was doubt over the quality of the artist, the lack of big names and difficulties with publicity. Whereas many sport fans could identify Zátopek or Blankers-Kern as heroes of '48, few are even aware of the artistic champions". (Barker, 2006, pp. 68-69).

In 1949, the IOC meeting was in Rome and there was an opinion that practically all the artists participating in the Olympics were professionals because they made their living from art. And because only amateurs are supposed to compete in the Olympic Games, art competitions should be cancelled and replaced by an art exhibition without awarding any prizes nor medals (Stanton 2002). This question sparked a heated debate, and it was decided less than a year before Helsinki 1952, that the art competitions would return to the Olympics after all. Like the British in 1908, the Finnish organizers pushed time out of the IOC's sudden decision, so unfortunately the art competitions could not be organized for logistical reasons. There was only an exhibition of works of art. At the 49th session of the IOC in Athens in 1954, the art competitions were finally cancelled.

\section{The Czechoslovak participation and successes}

Many Czech and Czechoslovak artists also made their mark in the history of the Olympic Games. They did not participate only in Antwerp 1920 and Amsterdam 1928. From Stockholm 1912 to

\footnotetext{
9 Jon Wils (1891-1971). When completed, the Olympic stadium had a capacity of 40,000 (seating for 1,600). The infield was a football field surrounded by an athletics and cycle track. The main stand had a steel roof. In 1987 the stadium was listed as a Dutch national monument. Since 2005, the stadium is home to a sports museum, the Olympic Experience Amsterdam.
} 
London 1948 it was 50 names altogether (Hladík, 2016, p. 15-23). The greatest successes were achieved by Czechoslovaks in the 1930s. Let me introduce them:

At the Olympic Games in Los Angeles 1932, Josef Suk ${ }^{10}$ won silver for the "Into a New Life" march. Gold and bronze were not awarded at that time and Josef Suk did not earn the title of Olympic champion mainly because the part of this composition was published in 1920 and thus the work did not fully comply with the competition rules. After the death of Josef Suk in 1935, the composition was recognized by the Sokol movement as their official march. ${ }^{11}$

In Los Angeles 1932, sculptor Jakub Obrovský (1882-1949) ${ }^{12}$ was awarded the bronze medal for the statue of Odysseus. A few years later, Jakub Obrovský was an important figure actively trying to push through the boycott of the 1936 Olympic Games in Berlin. He refused to participate in the "Hitler's Games".

Another success in the USA was noted by architect Aloys Dryák (1872-1932), who was awarded an honourable mention for the project of the Strahov Stadium in Prague, where the Sokol Slets took place.

The composer Jaroslav Křička succeeded in Berlin in 1936. His Mountain Suite was awarded a bronze medal. By the way, his brother Petr wrote the lyrics for Suk's march in Into a New Life.

In London, 1948, the distinguished Czech architect František Marek (1899-1971) received the honourable mention for the building of the Vinohrady Sokol Hall and musician Jan Kapr (1914-1988) for the composition Marathon. Kapr was an enthusiastic Communist after World War II, but in 1968 he fully opposed the occupation of Czechoslovakia by the Warsaw Pact troops and was banned by the Communists from any artistic activity subsequently.

Finally, let me mention the Traveling Prize of Czechoslovak Olympic Committee by Otakar Španiel (1881-1955), which is known today as the Dr. Jiř́ Stanislav Guth-Jarkovský13 Award. It did not receive any awards in Berlin, but it is an important part of the Czech Olympic movement. Since 1934 it has been awarded to athletes or sports teams for extraordinary sport performance in a given calendar year. After the Communist coup détat of 1948, it was abolished, but it was renewed by the Czech Olympic Committee in 1994. In recent years, the award has been given not by officials or journalists, but by athletes themselves, and so the prize enjoys extraordinary popularity in the Czech Republic.

\section{CONCLUSION}

We briefly outlined the history of art competition within the Olympic games. Since the cancellation of art contests, the so-called art festival has appeared at the Olympic Games, where the Olympic Charter has required organizers to include cultural events in the program. Until today,

\footnotetext{
${ }^{10}$ Josef Suk (1873-1935). An important Czech composer and violinist, student and son-in-law of the worldfamous composer Antonín Dvořák (1841-1904).

${ }^{11}$ See Marek Waic \& Zdeněk Škoda. (2019). The Story of a Composition: Josef Suk - Olympic Medallist and Sokol Composer. In The International Journal of the History of Sport, 35(17-18), 1829-1843. Retrieved from https://doi.org/10.1080/09523367.2019.1632292

${ }^{12}$ He devoted himself to fencing, tennis and boxing.

${ }^{13}$ Jiř́ Stanislav Guth Jarkovský (1861-1943) was a Czech sports promoter, Secretary General of the International Olympic Committee (1919-1923) and co-author of the Olympic Charter. He was a friend of Pierre de Coubertin since the time they met in 1892 in Paris. In 1900-1929 he was the chairman of the Czech and, after the establishment of the Czechoslovak Olympic Committee, co-founder and first chairman of the Czech Amateur Athletic Union, chairman and editor of the Tourist Club. He is also known as the author of publications on good and decent behavior.
} 
the combination of art and sport has continued without art competitions. But on the other hand, the opening and closing ceremonies are one of the most watched art-cultural events in the world. So even if the works of art themselves do not compete anymore, Olympism continues to relate to art.

\section{Literature}

Barker, P. (2006, May). London 1948. Journal of Olympic History, 14(special edition), 68-69.

Bijkerk, A. T. (2006, May). Amsterdam 1928. Journal of Olympic History, 14(special edition), 29.

Coubertin de, P. \& Müller, N. (2000). Olympism: Selected works (pp. 605-633). Lausanne: IOC.

Diem, C. (1937). XIth Olympic Games, Berlin 1936 Official Report (pp. 1106-1123). Berlin: Wilhelm Limpert.

Durry, J. (2000). Hohrod and Eschbach: A mystery finally solved. Olympic Review, 32.

Guillain, J. Y. (2005, November). The end of the Olympic Art Competition. Journal of Olympic History, 13(3), $24-31$.

Hladík, P. (2016). Naši umělci na olympijských hrách. In F. Kolář (ed.), Sport a umění: seminář Akademické sekce České olympijské akademie pořádaný ve dnech 18.-20. záři 2015 ve Vizovicích (pp. 15-23). Prague: ČOV.

Kolár̆, F. (1999). Jiří Stanislav Guth Jarkovský, (pp. 73-74). Prague: Olympia.

Lennartz, K. (2006, May). Antwerp 1920. Journal of Olympic History, 14(special edition), 18.

Müller, N. (1994). One hundred years of Olympic congresses. 1894-1994 (pp. 605-633). Lausanne: IOC.

Stanton, R. (2002). The forgotten Olympic art competitions. Victoria: Trafford Publishing.

The Games of the Xth Olympiad Los Angeles 1932 (pp. 748-765). (1933). Xth Olympiade Committee of the Games of Los Angeles, U.S.A. 1932.

Waic, M. \& Škoda, Z. (2019). The story of a composition: Josef Suk - Olympic medallist and Sokol composer. In The International Journal of the History of Sport, 35(17-18), 1829-1843. Retrieved from https://doi.org/10.1080/09523367.2019.1632292

Wassong, S. (2006, May). The elimination of the art contest. Journal of Olympic History, 14, 78-79.

Wassong, S. \& Lennartz, K. (eds.). (2006). Journal of Olympic History, 14(special edition), Lausanne: ISOH.

Zawadski. T. (2006, May). Berlin 1936. Journal of Olympic History, 14(special edition), 51-54.

Archive sources

Widimský, F. (n.d.). Los Angeles 1932 [A/3498]. Fond František Widimský, Volume I. Olympic Study and Information Centre of the Czech Olympic Committee, Prague.

Widimský, F. (n.d.). Berlin 1936 [A/3500]. Fond František Widimský, Volume 3. Olympic Study and Information Centre of the Czech Olympic Committee, Prague.

Widimský, F. (n.d.). London 1948 [A/3502]. Fond František Widimský, Volume 5. Olympic Study and Information Centre of the Czech Olympic Committee, Prague. 